\title{
A CONFIGURAÇÃO DOS ESPAÇOS LIVRES NOS GRANDES EMPREENDIMENTOS VERTICAIS DA GRANDE SÃO PAULO: AS QUADRAS-CONDOMÍNIO
}

\author{
OPEN SPACE CONFIGURATION IN LARGE APARTMENTS DEVELOPMENTS IN THE \\ GREAT SÃO PAULO - THE CONDOMINIUM-BLOCKS
}

Silvio Soares Macedo

Arquiteto, professor titular da FAUUSP e coordenador da pesquisa $O$ sistema de espaços livres e a constituição da esfera pública contemporânea no Brasil

lapquapa@usp.br

Guilherme Gabriel Alves

Arquiteto pela FAUUSP

guilherme.alves@usp.br

\section{RESUMO}

Este artigo tem como objetivo o estudo dos tipos, das formas de uso dos espaços livres e das edificações nos empreendimentos paulistanos configurados como quadras-condomínio, projetados, principalmente, nos últimos dez anos (referente aos anos 2000), nos principais municípios da Grande São Paulo. São analisadas as questões projetuais que envolvem os padrões arquitetônicos, as volumetrias, os padrões de implantação, o tratamento paisagístico, a configuração e as funções dos espaços livres.

Palavras-chave: Espaços livres, empreendimentos verticais, quadras-condomínio, paisagismo, Grande São Paulo.

\begin{abstract}
This article aims to study the types and way of use of open spaces and buildings in the enterprises set up as paulistanos-condominium blocks, designed especially over the past 10 years (for the year 2000) in major cities of Greater Sao Paulo. It analyzes issues involving projective architectural patterns, the volumetrics, patterns of deployment, the landscaping, the configuration and functions of open spaces.
\end{abstract}

Keywords: Open spaces, vertical developments, condo-blocks, landscaping, greater São Paulo.

\section{INTRODUÇÃO}

São utilizados como referenciais de pesquisa os empreendimentos com maior evidência no mercado da Grande São Paulo. A ênfase está nos empreendimentos em fase de lançamento ou construção, destinados às classes médias e médias altas, formadores de enorme público consumidor em São Paulo. Para ilustrar e compreender a configuração dos espaços livres nesses conjuntos, foi utilizado como método o levantamento de inúmeros casos (cerca de 100), com a posterior subdivisão em categorias. 
Com essa amostra foi possível elaborar tipos que reúnem características básicas do grupo de objetos selecionados, ressaltando as diferenças, semelhanças, variações e equivalências. Foram identificados sete tipos de empreendimentos, descritos e detalhados com exemplos caso a caso. As denominações utilizadas têm por objetivo o entendimento do universo de empreendimentos existentes, não se referindo, inicialmente, a um condomínio em particular.

Este artigo tem como principal objetivo a identificação dos principais padrões de espaços livres particulares presentes em uma parcela da produção do mercado imobiliário de São Paulo: as quadras-condomínio, destacando os casos mais emblemáticos.

\section{A QUADRA-CONDOMÍNIO}

Os empreendimentos quadras-condomínio sugerem diferentes maneiras de dispor e qualificar os espaços livres particulares, criando perfis de paisagem, substituindo as formas tradicionais de vida, hábitos, hierarquias espaciais e funcionais.

Com esses empreendimentos, o projetista pode explorar novas formas de implantação de edificações, pois as questões de divisas e alinhamentos são mais flexíveis, não existindo mais a divisão tradicional de lotes, sendo a quadra a unidade mínima.

Os edifícios que, tradicionalmente, eram implantados com as faces paralelas aos limites do terreno, passam a ser dispostos de um modo menos convencional, possibilitando a criação de espaços maiores, pois não são atendidos apenas os alinhamentos e parâmetros construtivos (como os recuos mínimos), mas sim as necessidades de ventilação e iluminação natural dos edifícios, assim como parte dos desejos dos projetistas e incorporadores.

Existe maior flexibilidade de dispor equipamentos de esporte e lazer, assim como o enriquecimento do tratamento dos espaços livres. Esses, nas quadras-condomínio são mais expressivos e, além de tudo, mais contínuos do que os presentes nos edifícios isolados em um lote.

Fato comum em lotes ocupados por apenas um ou dois edifícios, é a fragmentação dos espaços livres em espaços menores, que podem ser divididos em muitos outros espaços com funções e características distintas. Essa fragmentação favorece a criação de espaços sem função ou uso definido, a maioria deles acaba sombreado pela própria edificação ou pelas construções próximas.

Na situação lote a lote, observada no nível de uma quadra urbana, é evidente o desperdício de áreas livres, situação que poderia ser evitada com outros tipos de assentamento de edifícios.

Esse novo padrão de implantação dos edifícios em conjuntos no terreno influencia diretamente a produção dos espaços livres e de seu entorno próximo, portanto, o contexto urbano. Quadras inteiras são reservadas para um empreendimento, que permitirá a criação, com significativa liberdade, de algumas torres residenciais, generosos espaços livres de esporte e lazer, além de infra-estrutura básica de serviço e comércio (em alguns casos). 


\section{CLASSIFICAÇÃO TIPOLÓGICA}

É possível distinguir e reconhecer os condomínios-quadra, em relação à sua configuração morfológica e tipos de espaços livres, enquadrando-os nas classificações, por meio de algumas características, como:

- A dimensão do conjunto, envolvendo tamanho do lote, número de edifícios, a variedade de equipamentos recreativos e esportivos;

- configuração e distribuição dos edifícios dentro do lote, podendo circundar ou não as áreas mais importantes do condomínio;

- porte da composição vegetal; se existe apenas pequenos trechos com vegetação, se existem áreas com algumas árvores de grande porte, ou se existem grandes grupos arbóreos (como bosques, reservas, parques);

- quantidade, variedade e localização dentro do lote de equipamentos de esporte e lazer (como piscinas com raia olímpica, aquecidas, com formas e desenhos variados, quadras esportivas, dentre outras muitas opções descritas anteriormente nesta pesquisa;

- programa de uso do espaço livre principal, formando áreas ajardinadas, praças, clubes, parques ou estacionamentos.

A partir dessas características é possível enumerar seis tipos de empreendimentos: conjunto praça, clube, parque, estacionamento, misto residencial vertical/horizontal e misto residencial e comercial vertical.

\section{Conjunto praça}

O conjunto praça é aquele cuja configuração dos edifícios normalmente cerca o espaço livre principal, acompanhando o perímetro do lote. As paredes dos edifícios são elementos estruturadores do espaço.

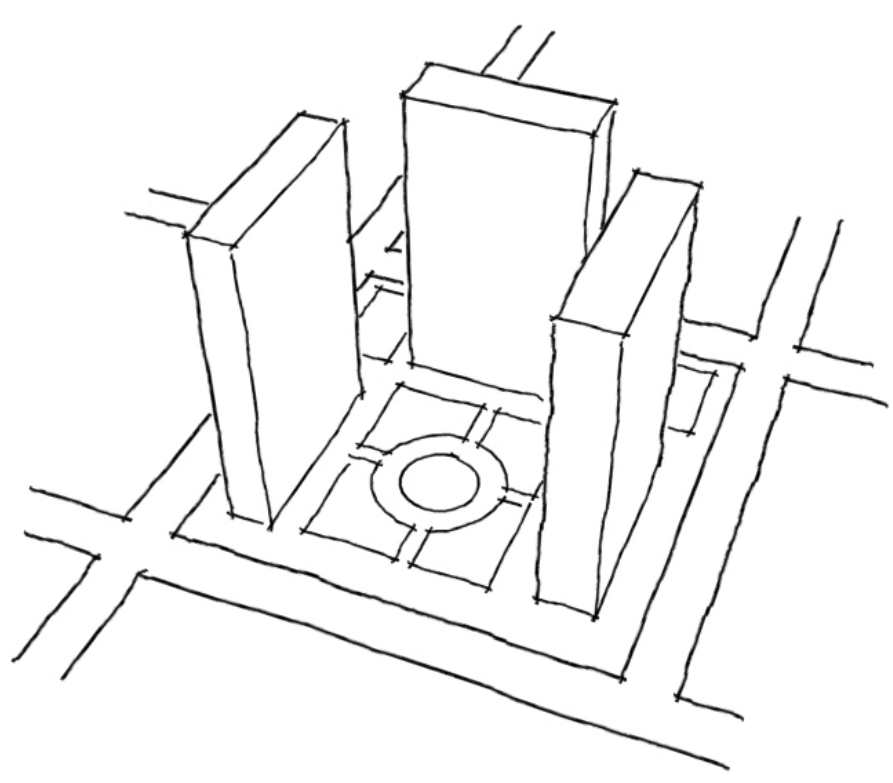

Figura 1: Esquema em perspectiva de um conjunto praça Fonte: Guilherme Gabriel Alves, 2009 
As formas que os edifícios possuem propiciam a criação de cenários, ou seja, pela linguagem arquitetônica da edificação e dos mais variados desenhos paisagísticos, sendo possível criar "microclimas" dentro dos conjuntos. Dessa forma, muitas vezes são criados espaços temáticos como praças em estilo "francês".

A geometria do espaço central é bastante diversificada, pois depende da forma do lote e da distribuição dos edifícios. A praça é ocupada por jardins ornamentais (desde os neoclássicos, com antigas e enormes palmeiras imperiais, até os mais contemporâneos com espelhos d'água e desenho minimalista) com vegetação de pequeno e médio portes, com alguns exemplos de árvores de grande porte.

Esses espaços são projetados "teoricamente" como área de encontros, com a permanência dos condôminos por algum tempo, ou simplesmente como cenários e passagem, enfatizando os elementos arquitetônicos e paisagísticos.

O número de torres varia bastante, mas os casos mais comuns são os de três e cinco edifícios. Já o número de andares dos edifícios, na maioria dos casos, não apresenta diferença. Em São Paulo, os últimos lançamentos (referentes aos anos 2008 e 2009) apresentaram alturas médias variando de 26 a 28 andares, dependendo do bairro em que se encontram.

Exemplos de conjuntos praça:

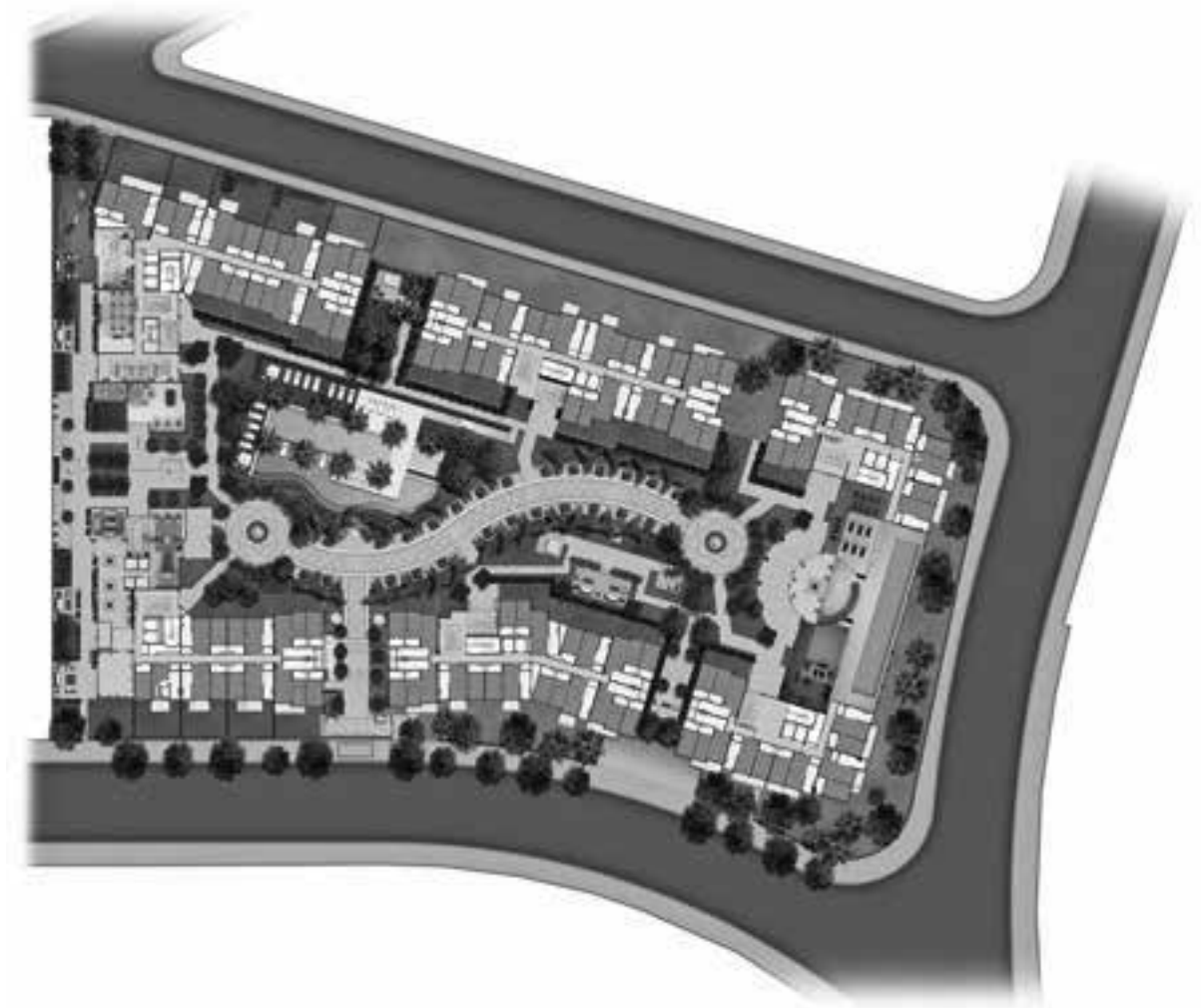

Figura 2: Implantação do Andalus - Morumbi

Fonte: Disponível em: <http://www.cyrela.com.br/sp>, 2009 


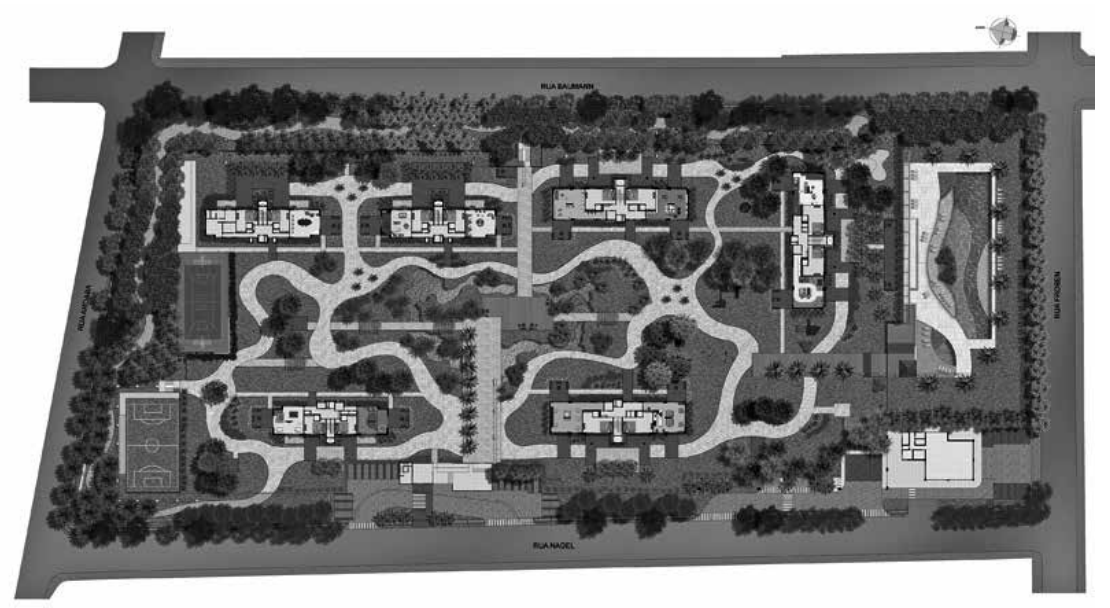

Figura 3:

Implantação do Vila Nova Leopoldina -

Vila Leopoldina Fonte: Disponivel em: <hHtp://www. vilanovaleopoldina. com.br/>, 2009

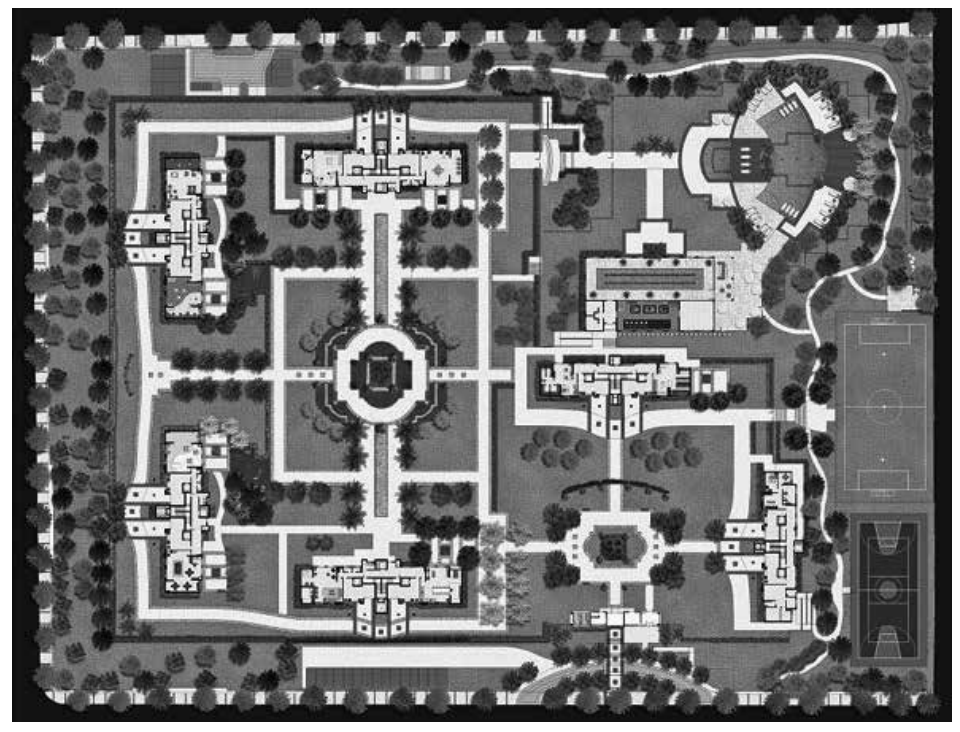

Figura 4:

Implantação do La

Dolce Vita Mooca -

Mooca

Fonte: Acervo

Quapá, 2007

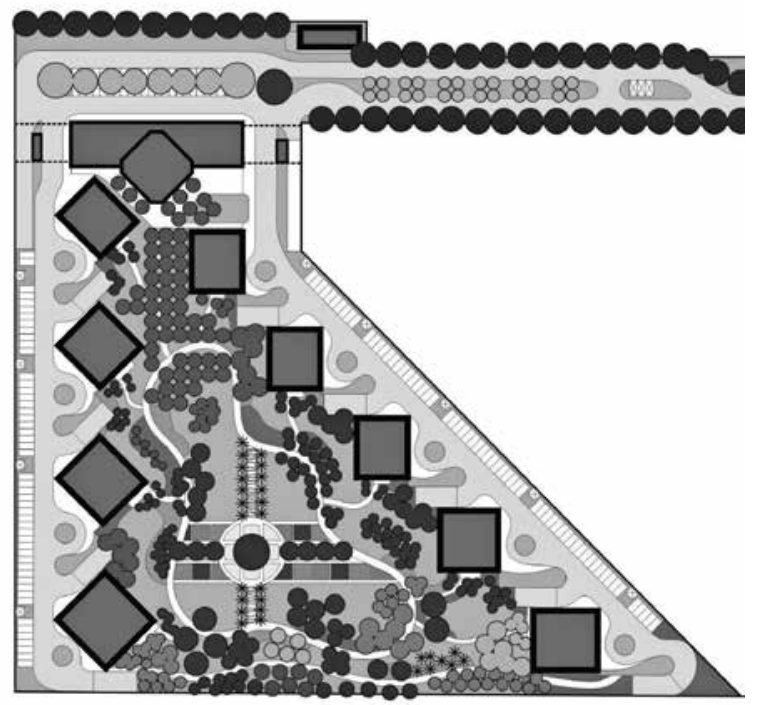

Figura 5: Implantação do Praça Villa Lobos Alto de Pinheiros Fonte: Acervo Quapá, 2008 
Um exemplo dessa categoria é o Praça Villa-Lobos. Esse empreendimento entregue no ano de 2009 foi implantado em terreno de $34.000 \mathrm{~m}^{2}$.

A praça central, considerada um dos grandes chamarizes de vendas do empreendimento, possui $13.000 \mathrm{~m}^{2}$ e é rodeada por nove torres residenciais de 25 pavimentos, possuindo apenas um apartamento por andar, somando 225 unidades.

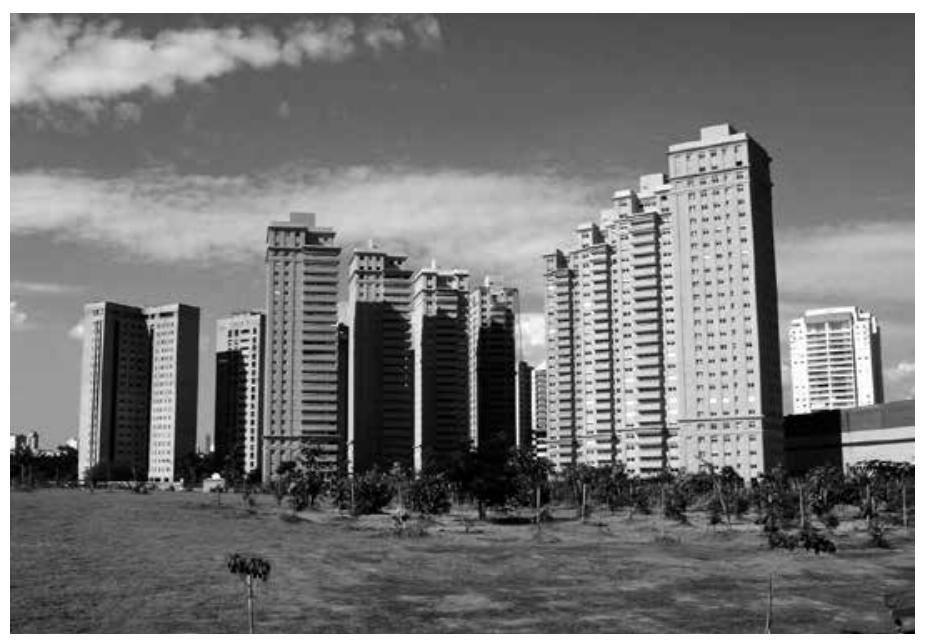

Figura 6: As nove torres estão voltadas para a praça central e para o Parque Villa-Lobos Fonte: Acervo pessoal de Guilherme Gabriel Alves, 2009

Os edifícios foram implantados seguindo o perímetro do terreno e configurando uma praça central cenário, a qual, de certa forma, está visualmente conectada com o parque Villa-Lobos. A área de lazer está concentrada em um prédio na lateral do terreno, próximo à portaria. $O$ empreendimento ainda possui uma alameda pública onde existe acesso ao Shopping Villa-Lobos.

\section{Conjunto clube}

Configura-se pela existência de clube na área central do terreno, onde se localizam grande parte dos equipamentos de recreação e lazer do empreendimento. No clube em geral existe: bar, restaurante, lanchonete, cinema, academia (alguns possuem até instrutores para auxiliarem as atividades realizadas nas piscinas ou quadras esportivas). Na área do clube existe, normalmente, vegetação de pequeno e médio portes (na grande maioria dos casos, com espécies tropicais - palmeiras de muitas espécies, por exemplo).

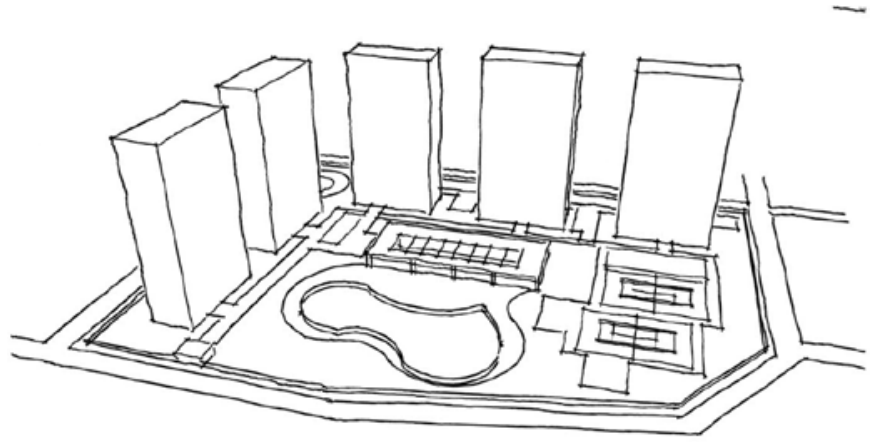

Figura 7: Esquema do conjunto clube com a valorização da área de lazer, normalmente projetada para ocupar o centro da implantação Fonte: Guilherme Gabriel Alves, 2009 
O clube é considerado o elemento principal, não se objetiva à construção de cenário, como é o caso do conjunto praça, mas as visuais proporcionadas pelos equipamentos do clube não deixam de ser elemento de atração para a venda dos empreendimentos.

Exemplos de conjuntos clube:

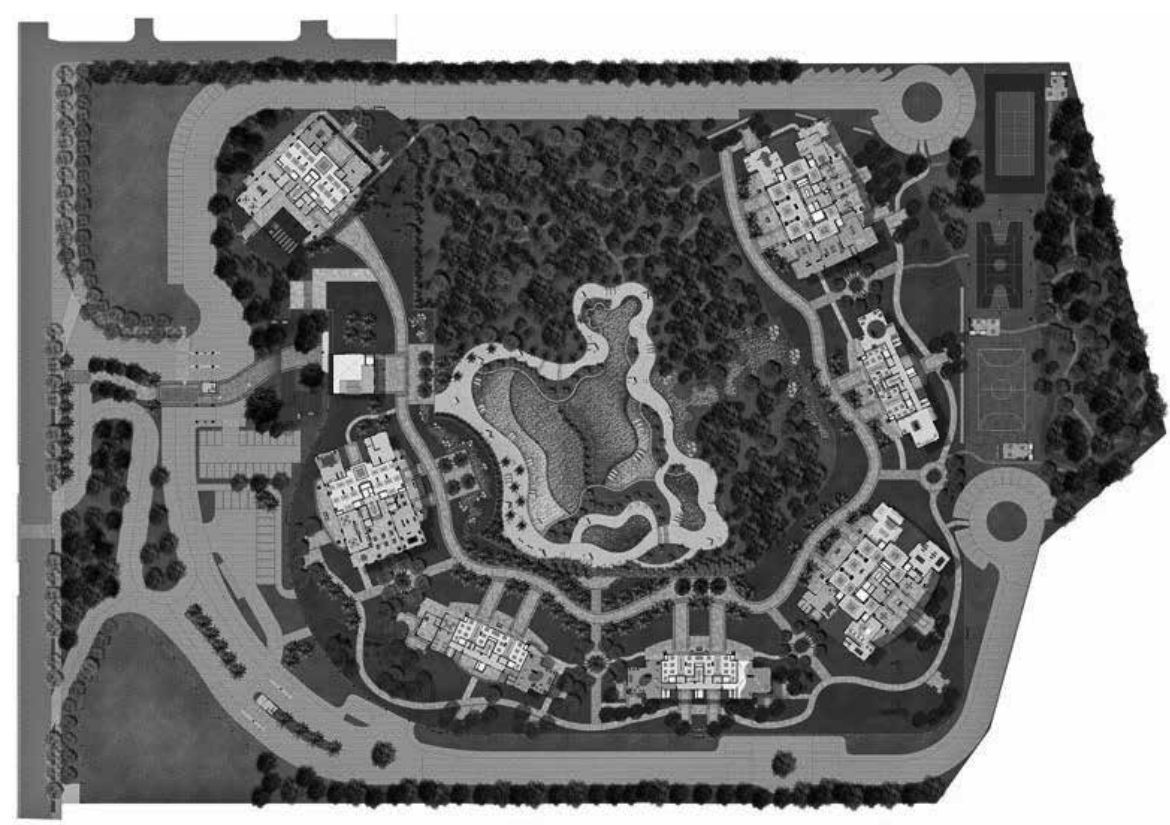

Figura 8: Implantação do Domínio Marajoara - Jardim Marajoara Fonte: Disponível em: <http://www.cyrela.com.br/sp>, 2009

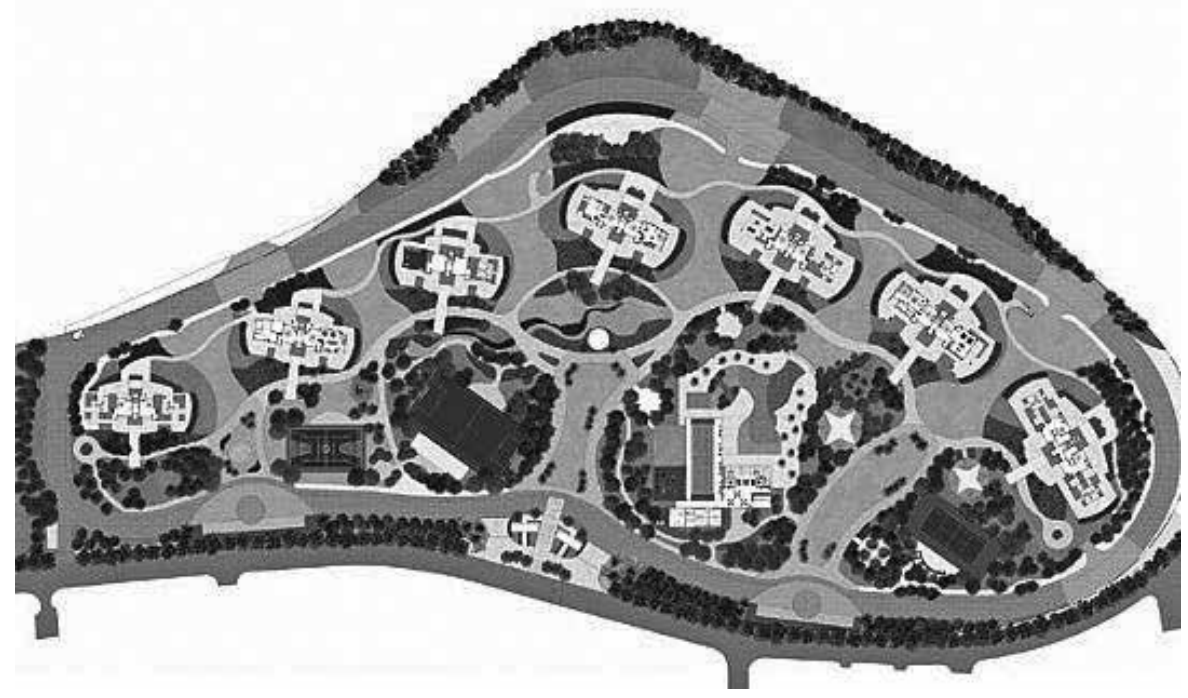

Figura 9: Implantação do Forte do Golf - Vila São Francisco

Fonte: Disponível em: <http://www.fortedogolf.com.br/>, 2009 
Illha do Sul, em Alto de Pinheiros, empreendimento histórico, foi um dos primeiros condomínios verticais em São Paulo a possuir espaço livre de lazer e recreação com porte de clube. Foi construído em 1973 e possui seis edifícios de 20 pavimentos distribuídos pelo terreno, configurando um espaço principal, no centro do lote, com todos os equipamentos recreativos do conjunto.

lote do empreendimento possui $28.473 \mathrm{~m}^{2}$, ocupados com seis torres distribuídas geometricamente pelo terreno, e com clube que possui piscinas, quadra de tênis, viveiro e playground. Além disso, ainda existe significativa infra-estrutura de serviço composta por lanchonete, restaurante, cabeleireiro, escola e agência bancária.

Em uma das laterais do terreno existe pequeno bosque com vegetação de médio e grande portes, além de estacionamento de visitantes e acesso de veículos para a garagem.

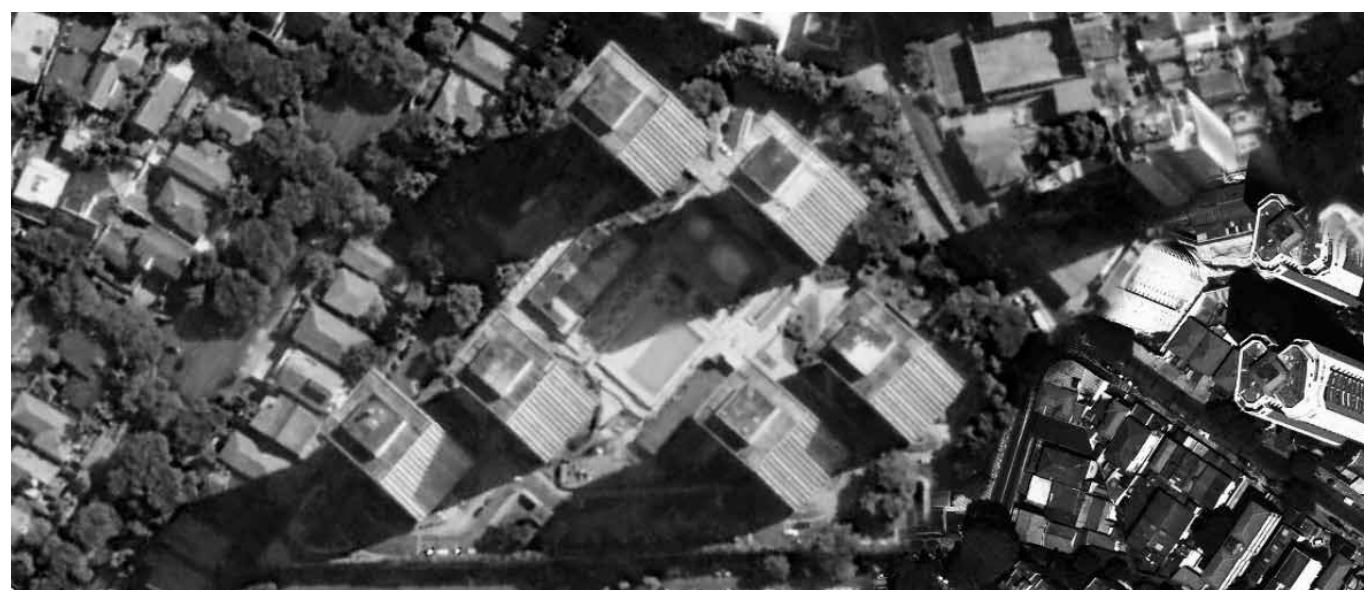

Figura 10: Imagem aérea do Ilha do Sul. No espaço livre central estão concentrados todos os equipamentos de lazer e recreação do condomínio Fonte: Google Earth, 2009

\section{Conjunto parque}

É distinguido das outras classificações, pois nesses conjuntos existem massas de vegetação que tanto podem ser remanescentes nativos quanto simplesmente árvores plantadas durante ou após a construção do empreendimento. Nesses conjuntos a forma do terreno é parcialmente preservada, pois, em alguns casos, existem nascentes e exemplares de vegetação de significativo valor.

Oterreno do conjunto parque, normalmente, é superior a $20.000 \mathrm{~m}^{2}$ e possui vias internas de circulação para automóveis. Em alguns casos existe padaria, restaurante, minishopping, cinema, dentre outras opções.

Os edifícios, normalmente, são distantes uns dos outros e formam algum tipo de alinhamento, ou circundam o parque principal ou são paralelos, ou ainda podem formar diagonais entre si.

Esses conjuntos foram pouco construídos na cidade de São Paulo até o fim da década de 1990. Quase todos os empreendimentos encontram-se no quadrante sudoeste do 


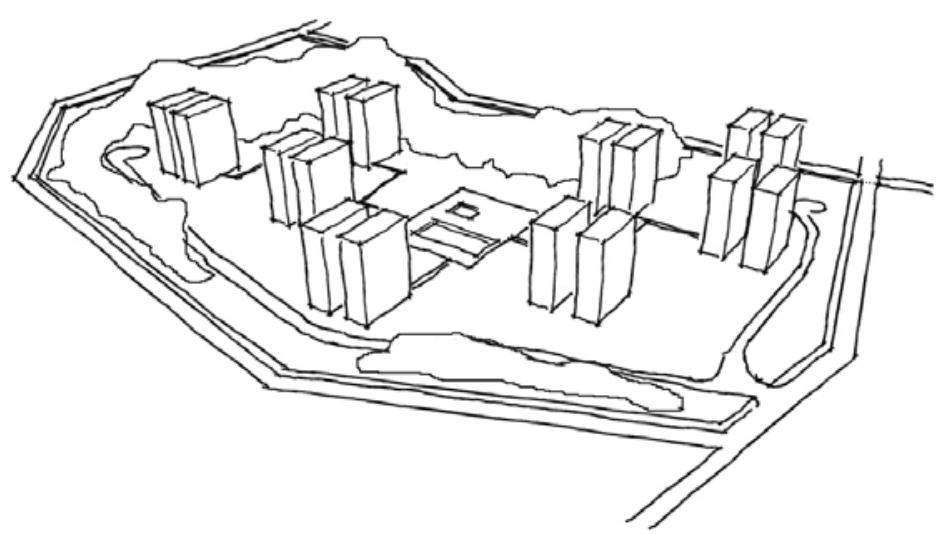

Figura 11: Esquema de um conjunto parque. Os edifícios são esparsos e possuem grandes áreas livres com vegetação, normalmente de médio e grande portes. Possuem área específica para atividades recreativas e até ruas internas para acesso aos edifícios e garagens

Fonte: Guilherme Gabriel Alves, 2009

município, como nos distritos do Morumbi e Vila Andrade. Essa categoria inexiste em trechos urbanos com quadras de $100 \times 100 \mathrm{~m}^{2}$, surgindo em locais onde os terrenos são superiores a $20.000 \mathrm{~m}^{2}$.

Exemplo de conjunto parque:

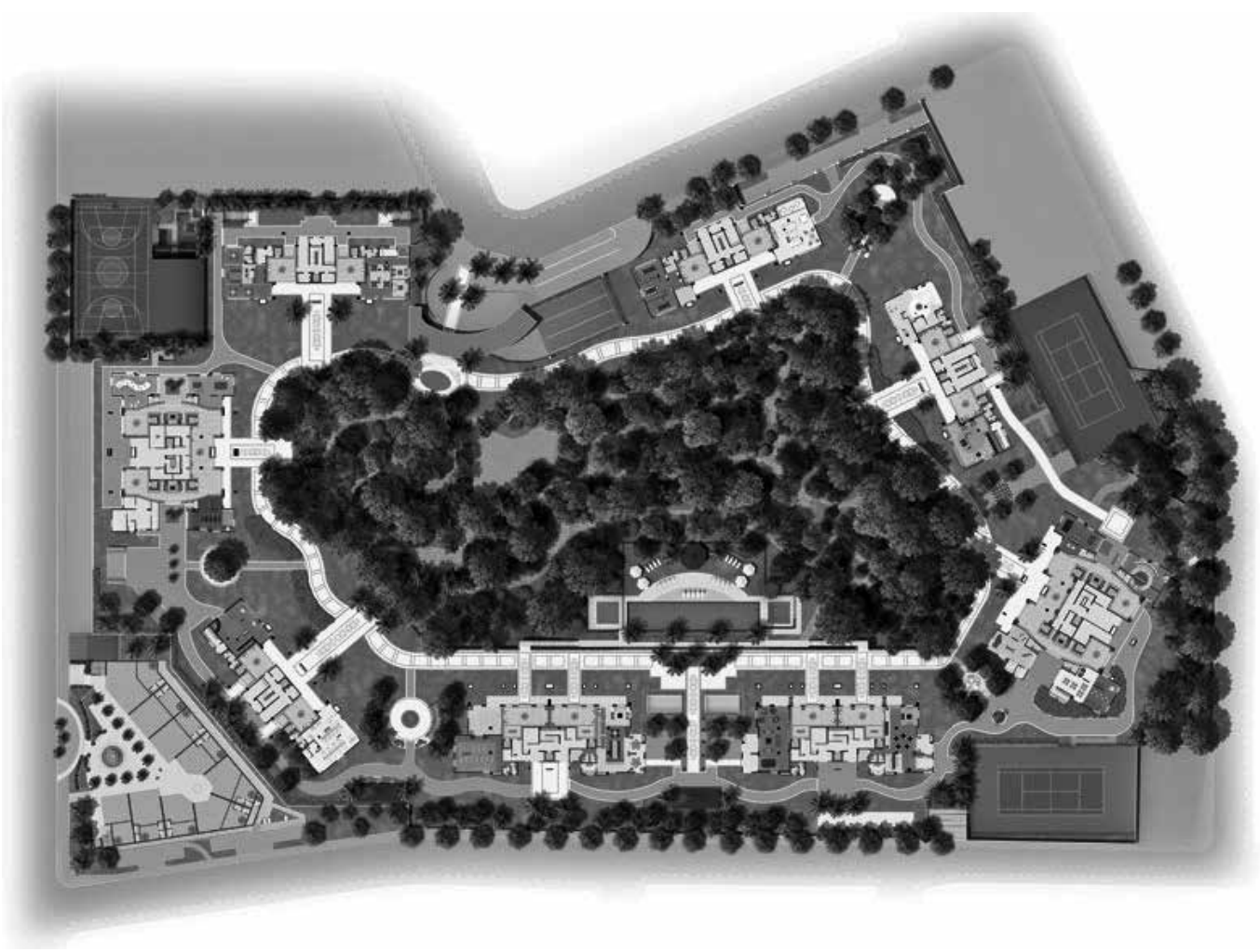

Figura 12: Implantação do Central Park Prime - Tatuapé

Fonte: Disponível em: <http://www.cyrela.com.br/sp>, 2009 
Villaggio Panamby é um exemplo de empreendimento tipo parque. Implantado em área maior do que o Portal do Morumbi (exemplo histórico, construído no final da década de 1970), com cerca de 260 mil m² e extensa área com vegetação conservada.

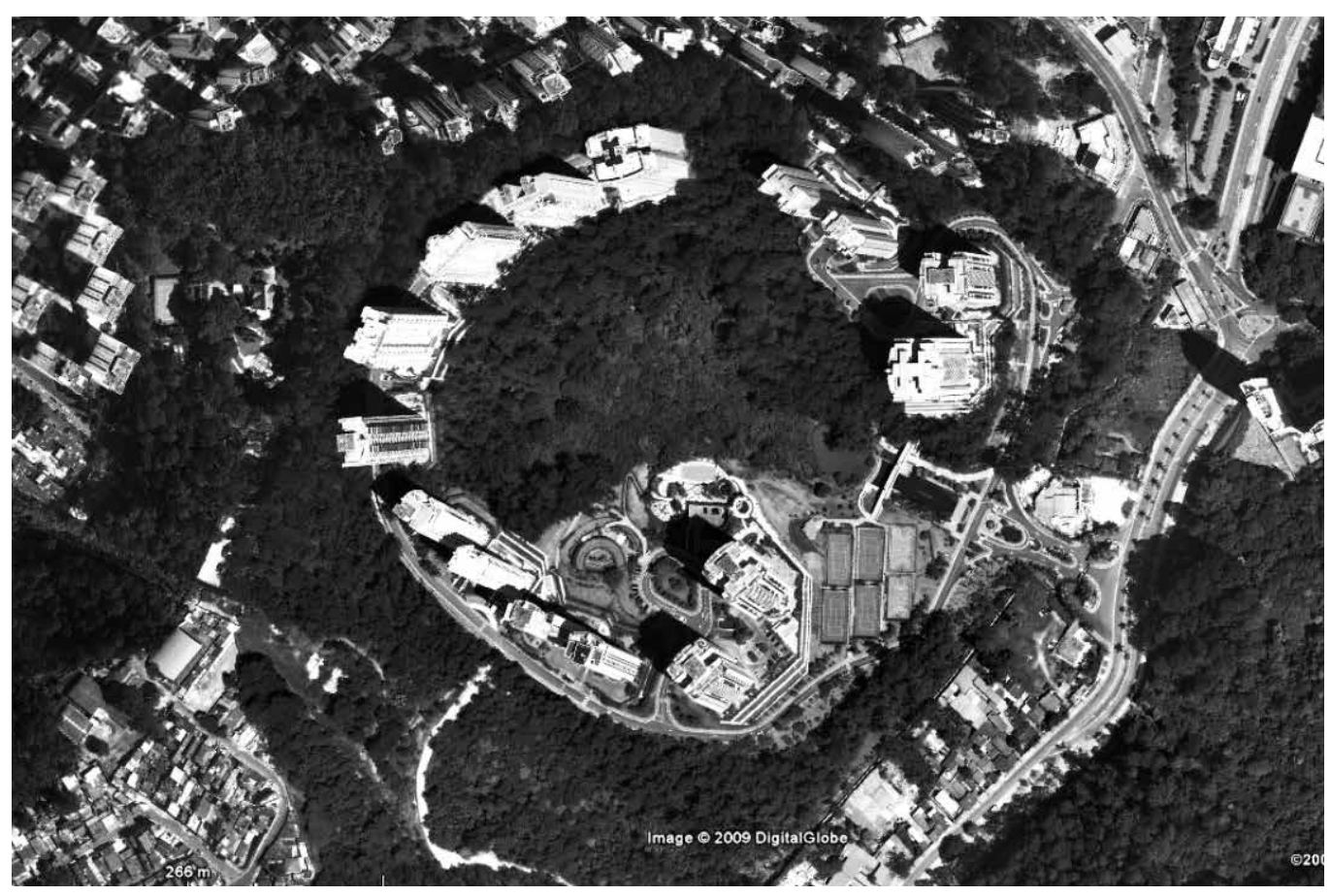

Figura 13: A imagem evidencia a importância do parque e os 15 edifícios ao seu redor Fonte: Google Earth, 2008

Nesse empreendimento a ideia de ter os edifícios circundando o ponto de atração acontece. Todos os 15 edifícios estão ao redor de um grande parque com vegetação remanescente, nascentes e lago natural de, aproximadamente, $58 \mathrm{mil} \mathrm{m}^{2}$. Dos 15 edifícios, 12 já foram entregues e outros três estão em fase final de construção (2010).

Existe um complexo recreativo que reúne vários equipamentos de esporte e lazer como quadras esportivas, piscinas (coberta aquecida e descoberta), spa, academia, restaurante, salão de beleza, creche, além de outras atividades e equipamentos.

Além de todos esses equipamentos de lazer do condomínio, cada edifício possui sua piscina, seu salão de festas e outros espaços para atividades específicas.

\section{Conjunto estacionamento}

Esses empreendimentos possuem estacionamentos ocupando grande porcentagem da área livre de edificação, o que proporciona baixa taxa de permeabilidade do solo. Em geral, esses condomínios estão implantados em terrenos de grandes dimensões com muitas torres residenciais. Existem exemplos com mais de 20 torres.

As áreas destinadas ao lazer e aos jardins são reduzidas a pequenas sobras ou recortes do terreno, e a vegetação de pequeno porte está presente em pequenos canteiros. 


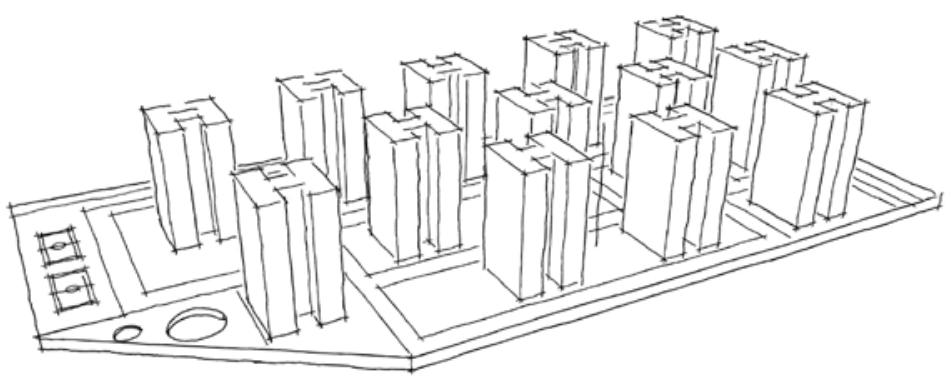

Figura 14: Esquema

de um conjunto

estacionamento.

Normalmente é

composto por mais

de 5 torres e possui

pouquíssima área

permeável

Fonte: Guilherme

Gabriel Alves, 2009

São raros os casos de conjunto estacionamento que possuem áreas de preservação e/ ou clube, com piscina e quadra esportiva.

Por causa de suas características, o valor dos imóveis é inferior, se comparados aos empreendimentos que possuem locais destinados às atividades recreativas ou contemplativas, e também por estarem localizados em regiões periféricas da cidade, com extremos das zonas leste e norte, assim como na região de Osasco.

Exemplos de conjunto estacionamento:

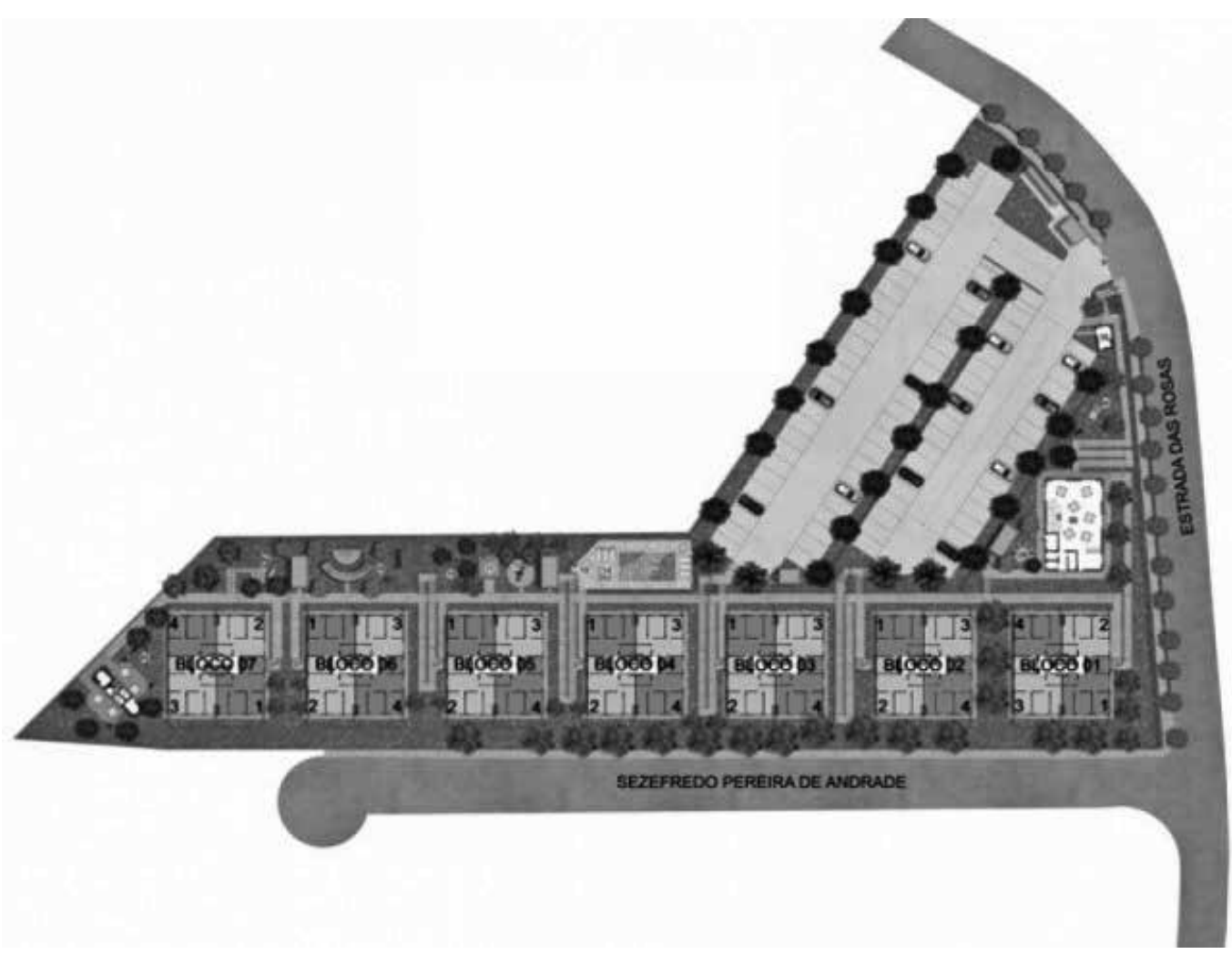

Figura 15: Implantação do Portal das Rosas - Guarulhos

Fonte: Disponível em: <http://www.tenda.com/>, 2010 


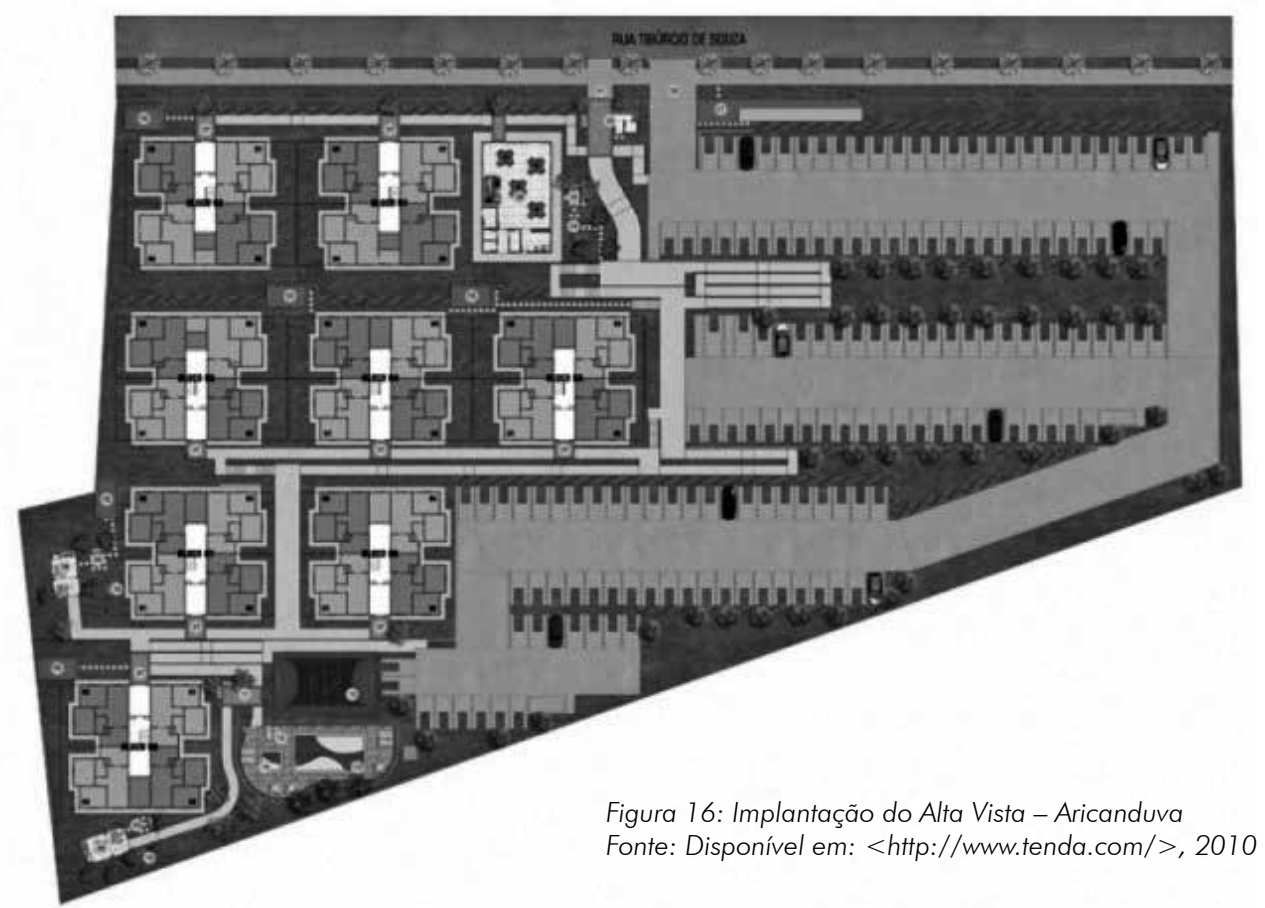

O Projeto Viver Belém, localizado no bairro Belém, da construtora Impar, é um exemplo de conjunto estacionamento, pois a grande maioria dos espaços livres de edificação é ocupado com vagas para automóveis. Existe uma rua que circunda todo o condomínio e dá acesso aos estacionamentos. Em alguns pontos existem churrasqueiras, praças, playground e quadras esportivas.

Ao todo são 28 torres residenciais de 16 andares, somando 1.792 apartamentos, dispostas de forma elementar, com pequenos recuos entre prédios, o que, em alguns momentos, cria locais sem iluminação e ventilação adequada.

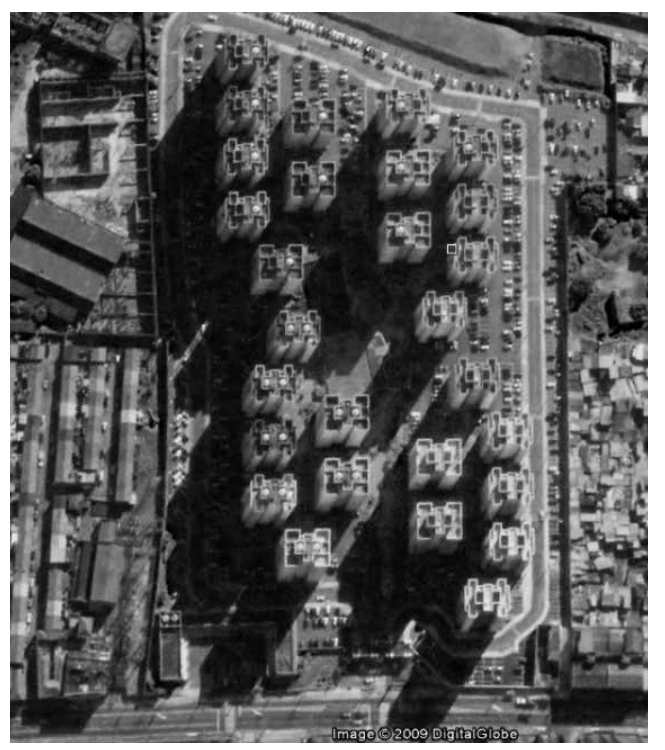

Figura 17: Vista aérea das 28 torres do conjunto residencial Fonte: Google Earth, 2008 


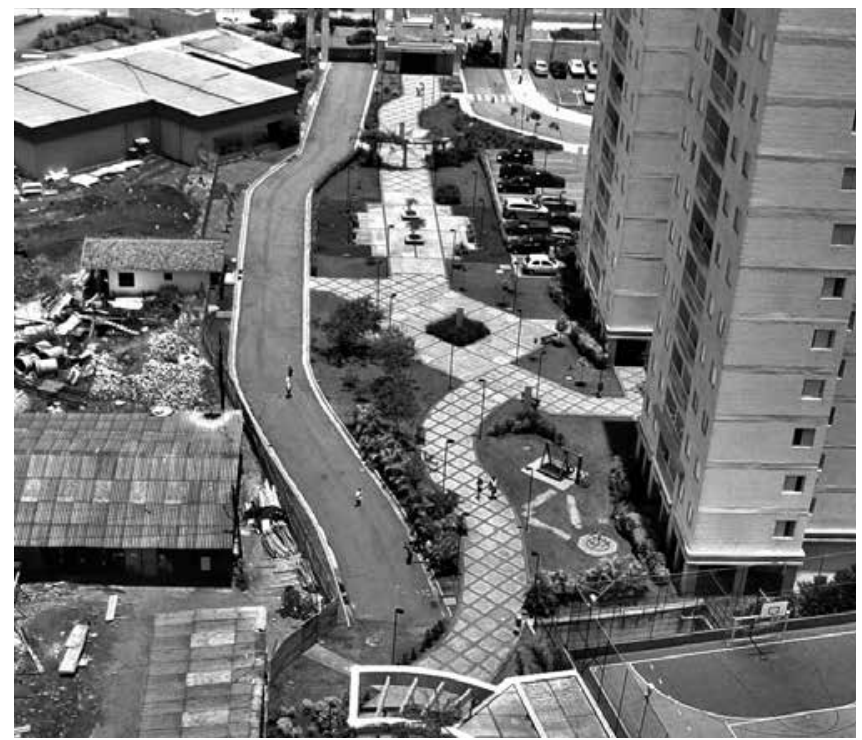

Figura 18: Vista dos espaços livres ocupados com garagens, acessos e jardins Fonte: Acervo Quapá, 2007

A rua que margeia todo o condomínio dá acesso a 1.792 vagas de estacionamento que são descobertas, cada apartamento tem direito a uma vaga. As vagas foram implantadas a cada duas, ou seja, o carro da vaga de trás depende da saída do carro da frente.

No centro da implantação existem áreas destinadas ao lazer, esporte e estar, mas a maior parcela do terreno é ocupada com estacionamento. $\bigcirc$ condomínio possui duas quadras - uma de futebol e uma poliesportiva, alguns quiosques com churrasqueira, distribuídos ao longo do espaço livre central, playgrounds e alguns caminhos de pedestres.

\section{Conjunto misto: residencial e comercial vertical}

Esse conjunto representa os empreendimentos que, além de possuírem os edifícios de uso residencial, também possuem, no mesmo terreno, uma ou mais torres destinadas ao uso comercial. Esses empreendimentos são relativamente novos na cidade de São Paulo, surgiram em maior número a partir dos anos 2000. Exploram a ideia de morar próximo ao trabalho, sem necessidade de usar carro ou outro tipo de transporte.

Normalmente, esse tipo de empreendimento é de grande porte e implantado em terrenos de, pelo menos, $20.000 \mathrm{~m}^{2}$, com algumas exceções.

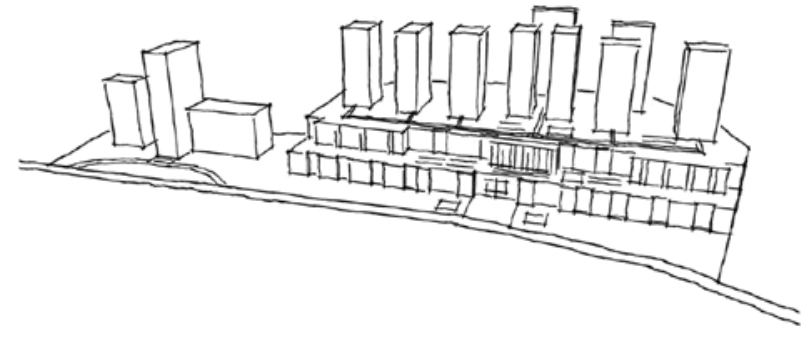

Figura 19: Esquema do Parque Cidade Jardim, um empreendimento que mistura edifícios residenciais e comerciais Fonte: Guilherme Gabriel Alves, 2009 
As torres residenciais, geralmente, possuem grande variedade de tamanhos de apartamentos e generosos espaços livres destinados às atividades de lazer e recreação. Já as torres comerciais são ocupadas por profissionais liberais, pequenas e grandes empresas, que chegam a ocupar um ou mais andares do edifício. Existem também alguns casos os quais, além da torre corporativa, existe outra ocupada com hotel ou flats, disponibilizando serviços diferenciados, pagos quando solicitados.

Exemplos de conjunto residencial e comercial vertical:

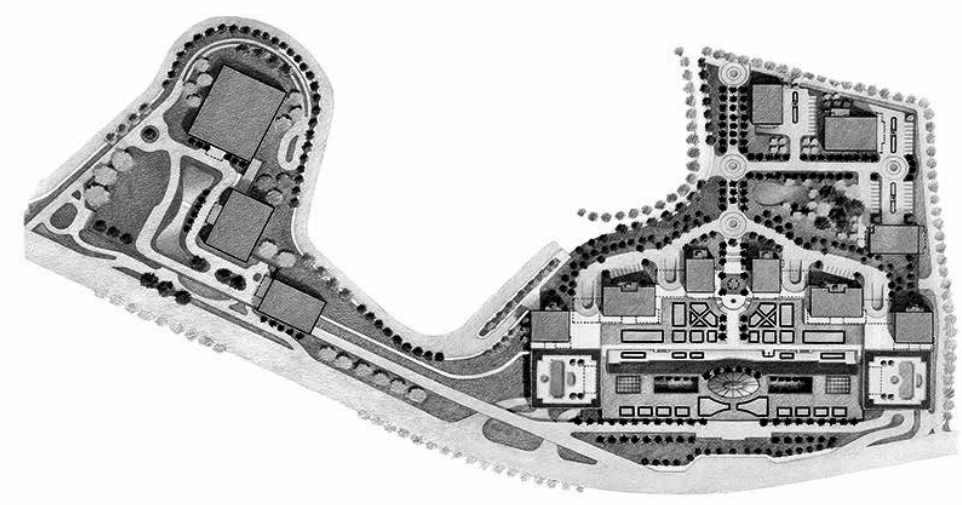

Figura 20: Implantação do Parque Cidade Jardim - Cidade Jardim

Fonte: Disponível em: < http://www.parquecidadejardim.com.br/>, 2009

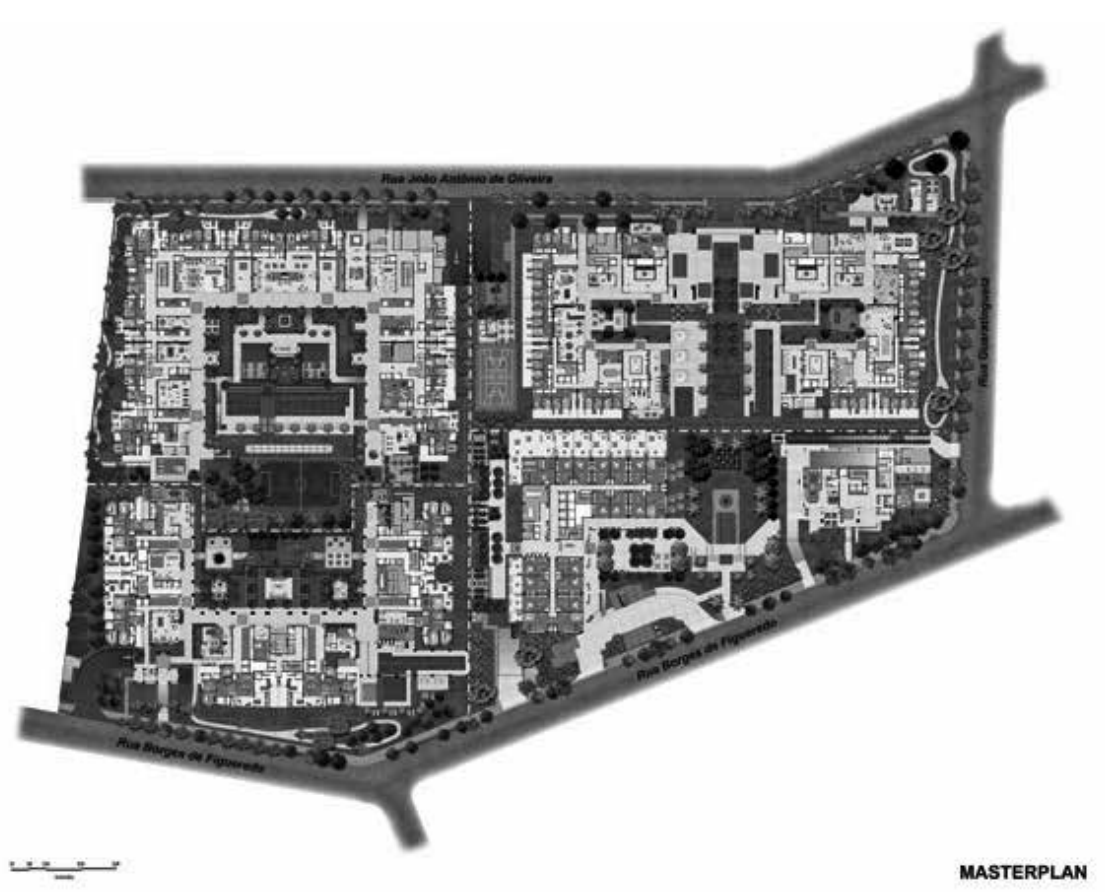

Figura 21: Implantação do Luzes da Mooca - Mooca

Fonte: Disponível em: <http://www.cyrela.com.br/sp>, 2009 
Um exemplo é o Novamérica, que será construído em terreno de 70 mil m² e terá seis edifícios residenciais de 28 pavimentos, um edifício comercial de 19 pavimentos e terá também uma vila comercial (escritórios de dois pavimentos).

A parte residencial possui uma grande praça central configurando cenário, com espaços de passagem, pequenos estares e elementos ornamentais, o acesso é realizado por todos os edifícios residenciais e permitido apenas aos moradores.

As partes comercial e residencial são independentes, o acesso só é possível pelas vias públicas que circundam todo o empreendimento, o qual ocupa uma quadra inteira.

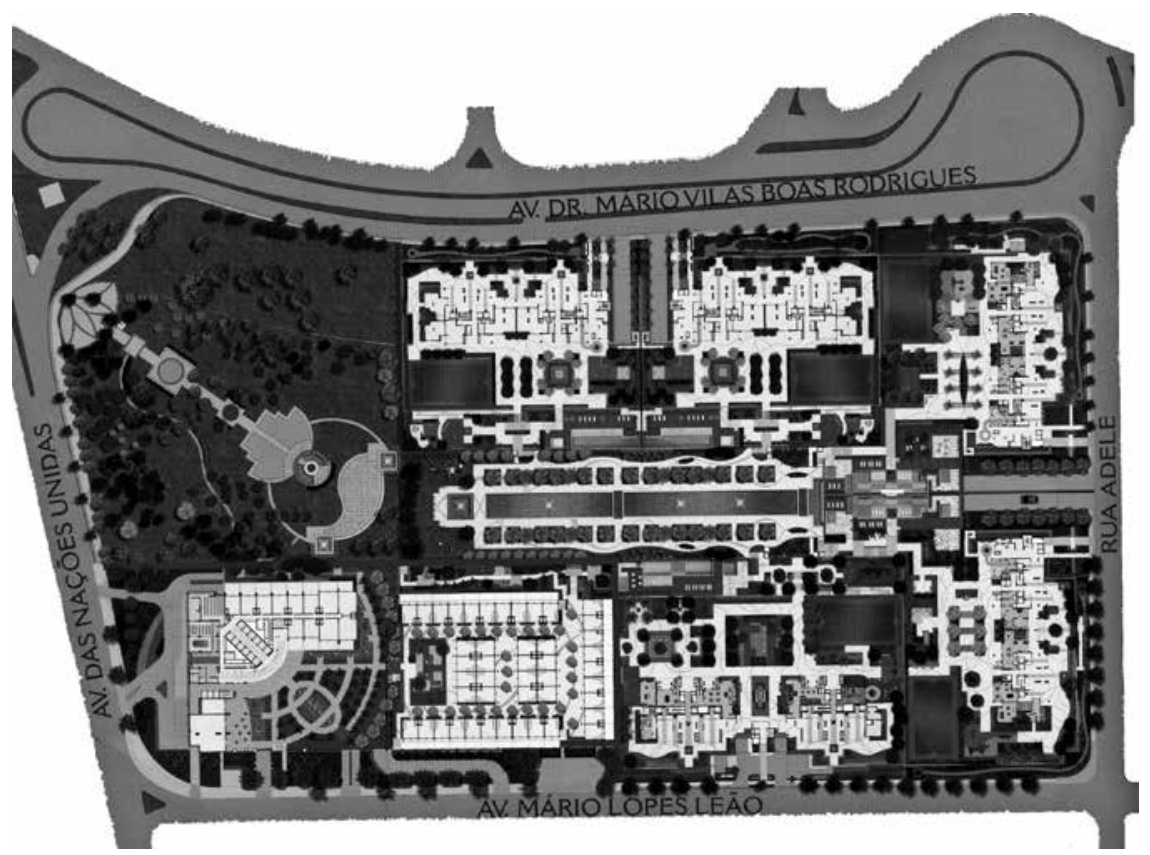

Figura 22: Imagem aérea do terreno localizado na avenida das Nações Unidas, local de fácil acesso para várias regiões da cidade

Fonte: Disponível em: <http://www.cyrela.com.br/sp>, 2009

\section{Conjunto misto: residencial vertical e horizontal}

Esse tipo se configura pela existência de edifícios residenciais e casas no mesmo empreendimento. As casas podem ser entregues prontas pela construtora, como casas de vila geminadas ou isoladas, ou então lotes para habitação unifamiliar.

Esses empreendimentos assumem características de bairro, pois possuem infra-estrutura básica de comércio e serviços como pequena padaria, lanchonete e banca de jornal, além de ruas internas. Em alguns empreendimentos são implantados apenas lotes, para progressiva construção das edificações, tanto as verticais quanto as horizontais.

Os espaços livres de lazer e recreação, em geral, estão concentrados em uma das extremidades da implantação. Os outros espaços livres como ruas e calçadas recebem tratamento paisagístico com árvores no recuo das casas e prédios, como também desenhos de piso. 


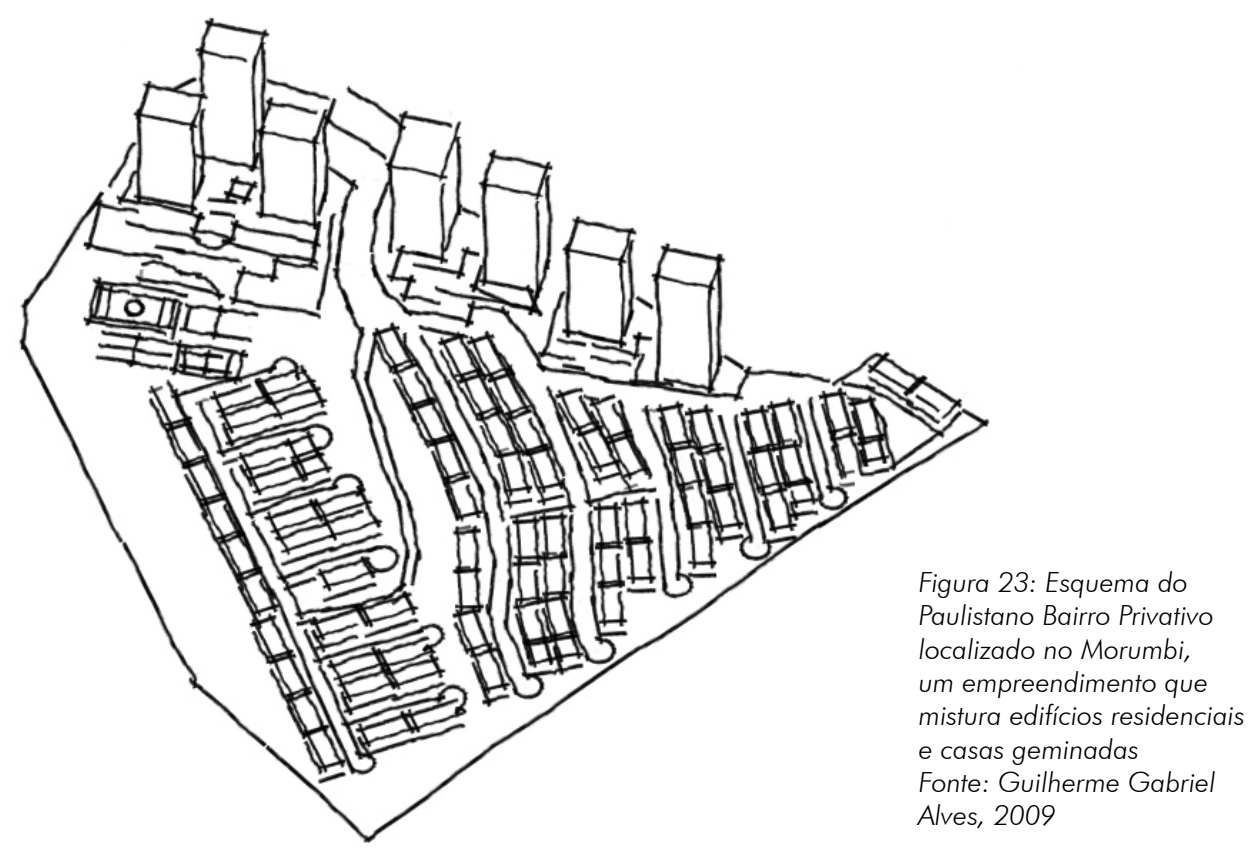

Exemplos de conjunto residencial vertical e horizontal:

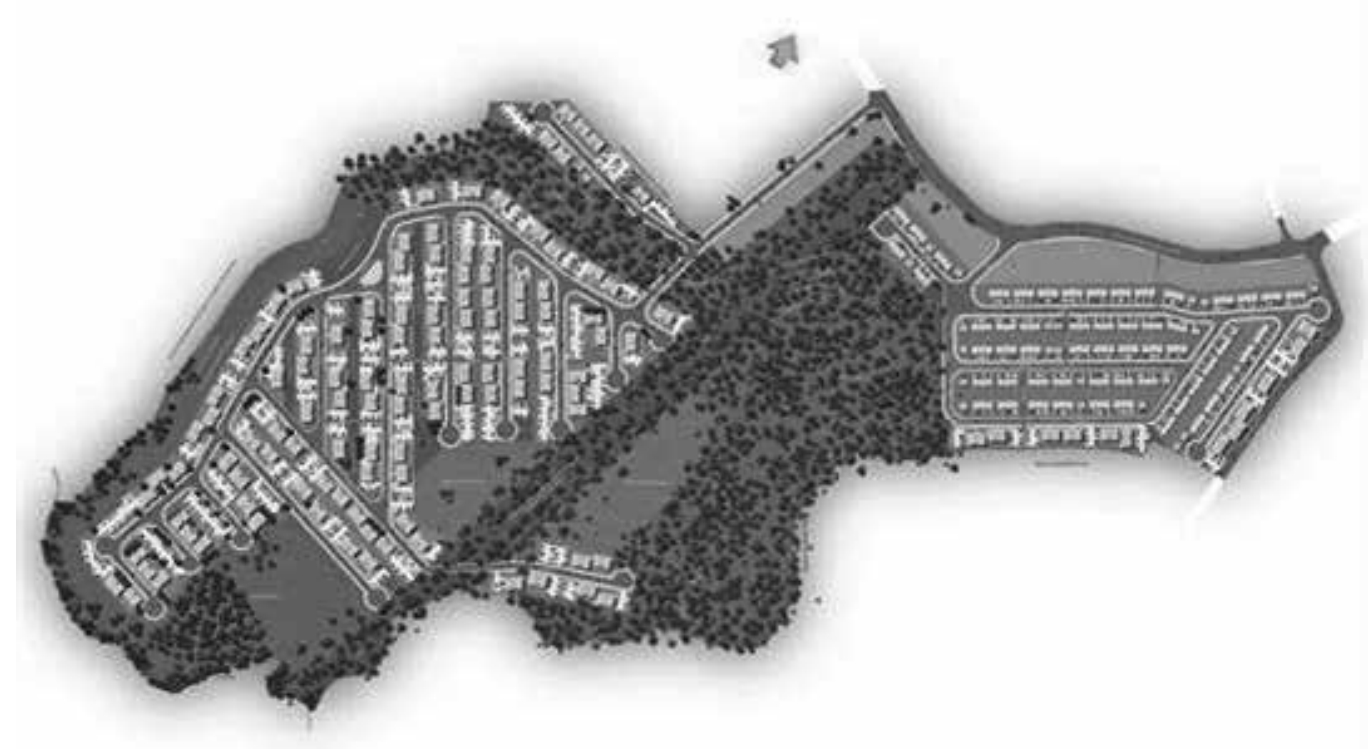

Figura 24: Implantação do Vale Verde Cotia - Cotia

Fonte: Disponível em: <http://www.tenda.com/>, 2009 


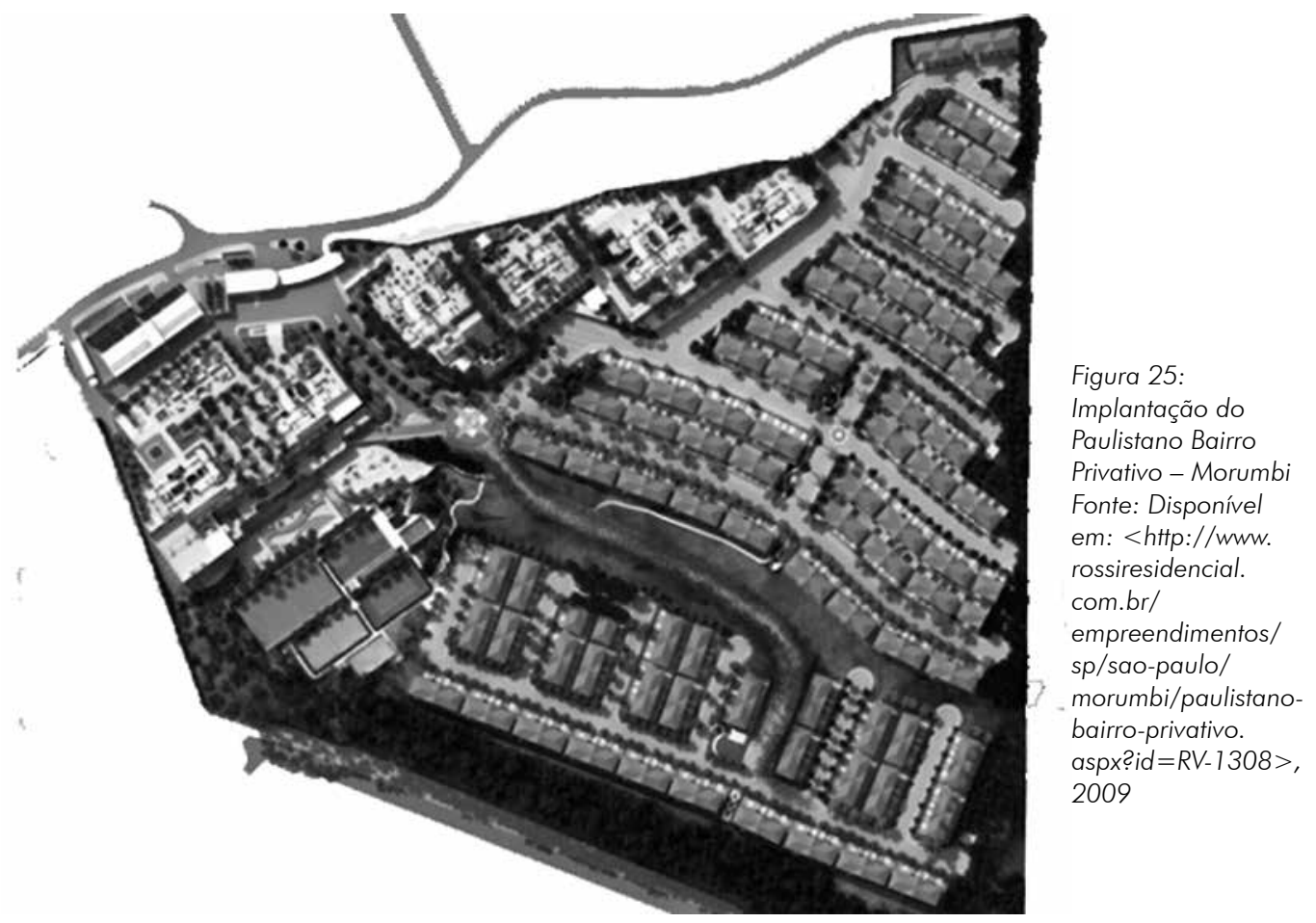

Todos esses tipos de empreendimentos foram possíveis na cidade de São Paulo em virtude de alguns fatores:

- Legislação urbanística do município, as obrigatoriedades de recuos, taxas de ocupação, de aproveitamento e de áreas permeáveis, influenciam na ocupação do lote e também na forma das edificações (número de pavimentos, dimensão dos pavimentos tipo, dentre outras exigências);

- a demanda crescente por espaços livres destinados às atividades de lazer e recreação, assim como áreas de conservação de massas arbóreas dentro dos condomínios fechados. Isso ocorre devido à deficiência de espaços livres públicos como parque e praças em São Paulo; esses estão concentrados em alguns pontos da cidade;

- a valorização dos espaços livres (áreas de lazer e convivência) nos empreendimentos por parte das incorporadoras, construtoras e imobiliárias, como elemento de atração do público consumidor;

- a questão das desigualdades e dos conflitos sociais, que geram tanto a segregação social quanto a espacial (aumentam cada vez mais a construção de condomínios fechados, com muitos investimentos em segurança).

Mesmo com essas classificações de conjuntos de edifícios, como método de entendimento e estudo de um grupo de empreendimentos similares, cada condomínio é único e possui suas próprias características, ou seja, possuem terrenos de formas, tamanhos, topografia e contextos urbanos distintos. A paisagem do entorno também não é a mesma, possuindo insolação, direção dos ventos, vegetação, números de pessoas e de veículos circulando distintos. 


\section{Bibliografia}

ABBUD, Benedito. Criando paisagens - guia de trabalho em arquitetura paisagística. São Paulo: Senac, 2006.

ARAGÃO, Solange Moura Lima de. Espaços livres urbanos: a produção da caracterização das áreas de uso comum dos conjuntos de edifícios de apartamento paulistanos (1990-2004). 2005. Tese (Doutorado) - Faculdade de Arquitetura e Urbanismo, Universidade de São Paulo, São Paulo, 2005.

GONÇALVES, Fabio Mariz. O desenho da paisagem e a relação entre os padrões de urbanização e o suporte físico. 1999. Tese (Doutorado) - Faculdade de Arquitetura e Urbanismo, Universidade de São Paulo, São Paulo, 1999.

MACEDO, Silvio Soares. Quadro do paisagismo no Brasil. São Paulo: FAUUSP; Banco Itaú, 1999.

.São Paulo, paisagem e habitação verticalizada: os espaços livres como elemento de desenho urbano. 1987. Tese (Doutorado) - Faculdade de Arquitetura e Urbanismo, Universidade de São Paulo, São Paulo, 1987.

MENNEH, Márcia Unti Halluli. Morfologia da paisagem urbana verticalizada: conflitos e padrões urbanísticos. 1997. Tese (Mestrado) - Faculdade de Arquitetura e Urbanismo, Universidade de São Paulo, São Paulo, 1997.

MEYER, Regina M, P. Metrópole e urbanismo: São Paulo dos anos 50. 1991. Tese (Doutorado) - Faculdade de Arquitetura e Urbanismo, Universidade de São Paulo, São Paulo, 1991.

REIS FILHO, Nestor Goulart. Quadro da arquitetura no Brasil. São Paulo: Perspectiva, 1970.

SACCHI, Even. Yojiro Takaoka: O construtor de sonhos. São Paulo: Asa, 2003.

SAKATA. Francine G. As linhas projetuais da arquitetura paisagística no desenho dos espaços livres dos edifícios de apartamento. 1994. Relatórios de pesquisa - Faculdade de Arquitetura e Urbanismo, Universidade de São Paulo, São Paulo, 1994.

\section{Sites}

Cyrela Brazil Realty: http://www.cyrela.com.br/sp;

Vila Nova Leopoldina: http://www.vilanovaleopoldina.com.br;

Forte do Golf: http://www.fortedogolf.com.br/;

Construtora Tenda: http://www.tenda.com/;

Parque Cidade Jardim: http://www.parquecidadejardim.com.br/;

Rossi: http://www.rossiresidencial.com.br/empreendimentos/sp/saopaulo/morumbi/paulistano-bairro-privativo. aspx? id $=$ RV-1308. 